\title{
Pembelajaran Berbasis Komputer Menggunakan Ms. Office 2019 Pada Siswa Di Smk Dwitunggal 1 Tanjung Morawa
}

\author{
Dharmawati*1, Imran Lubis², Risko Liza $^{3}$ \\ 1,2,3Program Studi Teknik Informatika, Fakultas Teknik dan Komputer, Universitas Harapan Medan \\ *e-mail: dharmawati66@yahoo.com
}

\begin{abstract}
The work world related to office administration, mastery of Microsoft Office is needed as an office administration work tool that must be mastered by vocational students. However, students of SMK Dwitunggal 1 Tanjung Morawa hasn't been maximal in mastering Microsoft Office 2019, especially in making mail merge on Ms. Word. They are only limited to know the use of Microsoft Office 2019 in the basic stages. Community Service method was the tutorial, the question and answer, and the practical method. The result of this activity was students' improvement in the ability and skills of making mail merge for letters, certificates and labels using Microsoft Office 2019. It hoped that Students of SMK Dwitunggal 1 Office Management Department understands to create mail and if they follow Competency Test for their mail merge material, they can pass and get a Competency Certificate that is given by the State.
\end{abstract}

Keywords: Learning, Microsoft Office 2019, Mail Merge

\begin{abstract}
Abstrak
Dunia kerja yang berhubungan dengan administrasi perkantoran, penguasaan Microsoft Office sangat dibutuhkan sebagai tools pekerjaan administrasi perkantoran yang harus dikuasai oleh siswi SMK. Namun siswa SMK Dwitunggal 1 Tanjung Morawa masih kurang maksimal dalam menguasai Microsoft Office 2019 khususnya dalam pembuatan mail merge di Ms. Word. Mereka hanya sebatas mengetahui penggunaan Microsoft Office 2019 ini dalam tahap dasar. Kegiatan Pengabdian masyarakat ini bertujuan untuk memberikan pelatihan pengenalan Aplikasi komputer Microsoft Office 2019 dalam pembuatan mail merge pada Microsoft Word kepada siswa Perkantoran. Metode yang digunakan yaitu metode tutorial, metode tanya jawab dan metode praktik. Hasil kegiatan ini adalah adanya peningkatan kemampuan dan keterampilan pembuatan mail merge untuk surat, sertifikat dan label dengan menggunakan Microsoft Office 2019. Dengan harapan Siswa SMK Dwitunggal 1 Jurusan Manajemen Perkantoran memahami pembuatan mail serta apabila nantinya ini akan mengikuti Uji Kompetensi materi mail merge mereka bisa Lulus dan mendapatkan Sertifikat Kompetensi yang diakui oleh Negara.
\end{abstract}

Kata kunci: Pembelajaran, Microsoft Office 2019, Mail Merge

\section{PENDAHULUAN}

Teknologi informasi memiliki perkembangan yang sangat pesat diberbagai bidang sebagai bekal bagi mereka dalam menghadapi perubahan dan tuntutan jaman pada era Revolusi Industri 4.0. Teknologi informasi adalah studi penggunaan peralatan elektronika, terutama komputer, untuk menyimpan, menganalisis, dan mendistribusikan informasi apa saja, termasuk kata-kata, bilangan, dan gambar [1]. Bidang pendidikan merupakan salah satu bidang yang sangat dipengaruhi oleh teknologi informasi, baik dalam proses pembelajaran formal di sekolah maupun nonformal berupa pelatihan di luar sekolah. Dengan menggunakan Teknologi Informasi dan Komunikasi, suatu proses dan kegiatan dapat dilakukan dengan cepat, mudah dan efisien. Pembelajaran dengan TIK (Komputer) lebih baik dibandingkan dengan menggunakan metode konvensional [2]. Pengembangan dan pemanfaatan media pembelajaran berbasis TIK baik yang bersifat offline maupun online, bisa dimanfaatkan sebagai bahan masukan bagi pihak- pihak yang berminat terutama pihak pendidik [3].Oleh karena, itu penguasaan terhadap perangkat teknologi komunikasi perlu diajarkan pada semua tingkatan termasuk kepada siswa-siswi sekolah kejuruan. 
Sekolah Menengah Kejuruan (SMK) adalah salah satu bentuk satuan pendidikan formal yang menyelenggarakan pendidikan kejuruan pada jenjang pendidikan menengah sebagai lanjutan dari SMP/MTs atau bentuk lain yang sederajat atau lanjutan dari hasil belajar yang diakui sama/setara SMP/MTs (UU Nomor 20 Tahun 2013, Pasal 18 ayat [3]. Pendidikan kejuruan merupakan pendidikan menengah yang mempersiapkan peserta didik terutama untuk bekerja dalam bidang tertentu [4]. SMK sebagai sekolah yang menyelenggarakan pendidikan kejuruan yang menerapkan program keahlian seperti teknik mesin, perkantoran, seni rupa, tata boga, administrasi dll mempunyai peran penting memberi bekal salah satunya hard skill yang menunjang profesional skill seperti memahami penggunaan komputer. Hard skill merupakan ketrampilan teknis dalam bidang ilmu pengetahuan dan teknologi yang diperoleh dari otodidak, bangku sekolah, kuliah, pelatihan [5]. Siswa perlu memahami program yang terdapat di Windows, program yang paling sering digunakan di Windows adalah produk dari Microsoft [6]. Didalam dunia kerja yang berhubungan dengan administrasi perkantoran, penguasaan Microsoft Office sangat dibutuhkan sebagai tools pekerjaan administrasi perkantoran yang harus dikuasai oleh siswi SMK.

Perangkat lunak Microsoft Office 2019 memiliki banyak fitur yang masih kurang familiar disebagian pengguna, terutama oleh siswa SMK. Hal tersebut dialami oleh siswa SMK Dwitunggal 1 Tanjung Morawa yang belum terbiasa dengan tools yang banyak disediakan pada perangkat lunak Ms. Word, Kendala yang sering dijumpai adalah kurang maksimalnya pembuatan fungsi mail merge di Ms. Word. Mereka sebatas mengetahui penggunaan Microsoft Office 2019 ini dalam tahap dasar. Padahal penggunaan Microsoft Office 2019 ini bisa membantu dan memudahkan dalam pekerjaan Administrasi Perkantoran, apabila Siswa SMK sudah dibekali dengan penguasaan Microsoft Office sampai dengan tingkat lanjut. Cakap dalam menggunakan Microsoft Word, Power Point dan Excel adalah salah satu syarat untuk melamar pekerjaan, penggunaan dalam kehidupan sehari-hari dan melanjutkan keperguruan tinggi [7].

Melihat permasalahan diatas, dirasakan perlu dilakukannya kegiatan yang mampu meningkatkan kemampuan dari Siswa SMK Jurusan Manajemen Perkantoran dalam penguasaan Microsoft Office 2019 ini. Sehingga harapan siswa SMK siap kerja dapat menjadi kenyataan. Kegiatan ini akan dilakukan melalui kegiatan pengabdian pada masyarakat di Prodi Teknik Informatika Fakultas Teknik dan Komputer sebagai salah satu kegiatan Tri Dharma Perguruan Tinggi yang menjadi kewajiban seluruh dosen. Kegiatan PPM ini akan dilakukan di SMK Dwitinggal 1 yang terletak di Kecamatan Tanjung Morawa Kabupaten Deli Serdang. Peserta yang menjadi sasaran kegiatan ini adalah para Siswa-siswa SMK jurusan Manajemen Perkantoran. Kegiatan ini berupa pelatihan dengan menekankan pada penguasaan terhadap teori dan praktek penggunaan Microsoft Office 2019 tingkat lanjut khususnya pembuatan mail merge. Dengan mail merge, kita dapat membuat dokumen yang memiliki perbedaan unik dan serupa pada posisi yang sama sehingga tidak perlu membuat dokumen yang sama berulangulang [8]. Pembuatan mail merge untuk surat, sertifikat dan lebel dengan menggunaan Microsoft Word dengan merupakan contoh-contoh kasus yang biasa terjadi didunia kerja dan dapat diselesaikan dengan menggunakan bantuan tools di Microsoft Office 2019 yang akan digunakan dalam kegiatan pelatihan ini. Microsoft Office 2019 merupakan Microsoft Office terbaru [9]. Dengan harapan Siswa SMK Dwitunggal 1 Jurusan Manajemen Perkantoran memahami pembuatan mail marge untuk surat, sertifikat dan label serta apabila nantinya ini para siswa akan mengikuti Uji Kompetensi materi mail merge mereka bisa Lulus dan mendapatkan Sertifikat Kompetensi yang diakui oleh Negara.

\section{METODE}

\subsection{Metode}

Metode pelaksanaan kegiatan pengabdian yang akan dilaksanakan untuk mengatasi permasalahan adalah berikut ini. 
1. Metode Tutorial

Metode ini digunakan untuk menjelaskan materi dasar dan pengetahuan tentang Microsoft Office 2019. Selain itu metode ini juga digunakan untuk memberikan pemahaman tentang pembuatan mail merge yang dapat digunakan untuk membuat sertifikat, label, dan amplop pada Ms. Word. Pada tahap pemberian materi, para peserta diberikan modul yang digunakan sebagai alat bantu dalam kegiatan pelatihan.

2. Metode Tanya Jawab

Metode ini digunakan untuk mengetahui sejauh mana pengetahuan peserta pelatihan terhadap materi yang telah dijelaskan.

3. Metode Praktik

Pada metode ini para siswa akan mempraktekkan semua materi yang telah dijelaskan sebelumnya. Metode ini digunakan untuk mengetahui sejauh mana pengetahuan dan kemampuan para siswa dalam membuat tugas mail merge untuk membuat sertifikat, label, dan surat pada Ms. Word. Dan diakhir pelatihan peserta pelatihan akan diberikan angket respon para peserta terhadap pelatihan telah dilakukan.

\section{2 Kerangka Pemecahan Masalah}

Adapun kerangka pemecahan masalah dalam pelatihan Pembelajaran Berbasis Komputer Menggunakan Ms. Office 2019 Pada Siswa di SMK Dwitunggal 1 Tanjung Morawa dapat dilihat pada gambar dibawah ini.

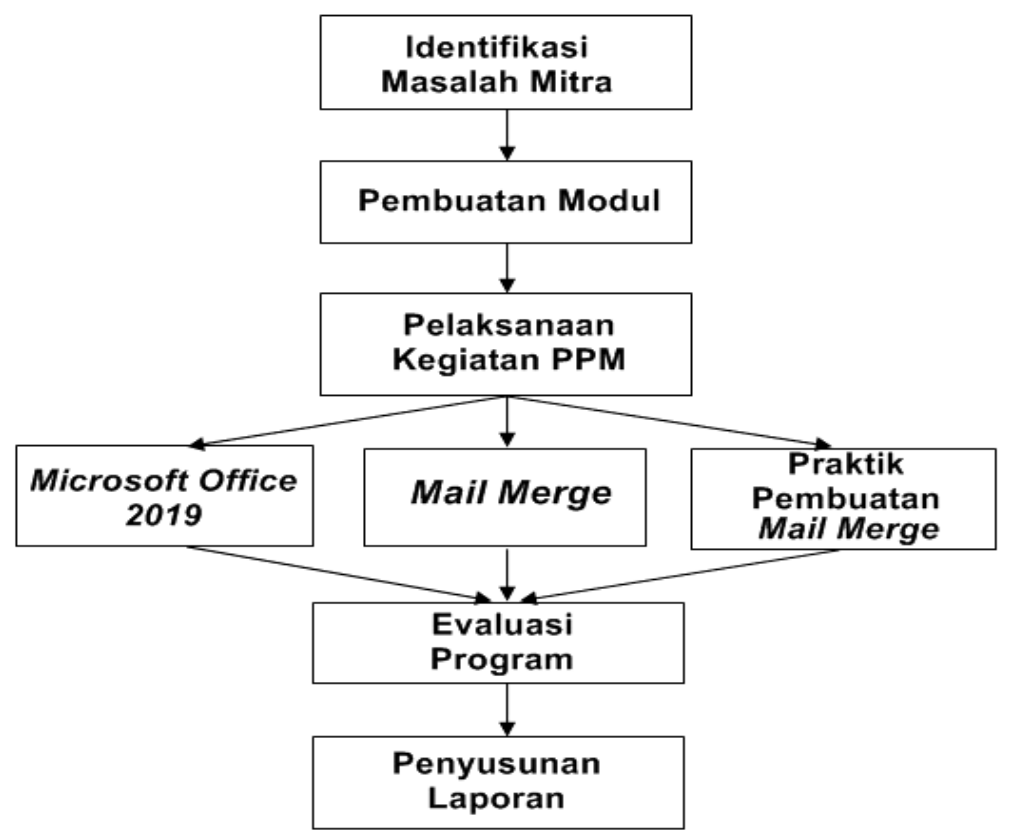

Gambar 1 Kerangka Pemecahan Masalah

\subsection{Realisasi Pemecahan Masalah}

Untuk memecahan masalah dalam pencapaian memberikan informasi tentang pemanfaatan komputer dalam pembelajaran pada siswa SMK Dwitinggal 1 maka perlu diadakannya pelatihan. Dalam kegiatan pelatihan ini peserta diberikan penjelasan mengnai aplikasi Microsoft Office 2019 dan pembuatan mail merge pada Ms. Word.Dalam pelaksanaan pelatihan ini akan melibatkan 3 (tiga) orang dosen dan dibantu oleh 2 (dua) orang mahasiswa, hal ini dilakukan dengan tujuan agar kegiatan pelatihan ini mempunyai manfaat yang benar- 
benar dapat dirasakan oleh peserta pelatihan karena segala kesulitan-kesulitan peserta selama mengikuti pelatihan akan dapat diatasi dan peserta akan mendapatkan bimbingan yang optimal.

\section{HASIL DAN PEMBAHASAN}

\subsection{Hasil}

Kegiatan pengabdian pada masyarakat ini dilaksanakan selama 3 bulan, bertempat di SMK Dwitunggal 1 Tanjung Morawa Kecamatan Deli Serdang Sumatera Utara. Siswa yang ikut dalam egiatan ini sebanyak 38 orang. Selama kegiatan tim dosen membawakan materi pembelajaran secara bergantian. 3 orang dosen tim kegiatan PPM dibagi menjadi 2 orang pengajar. Kedua pengajar di masing-masing kelas tersebut melaksanakan kegiatan pembelajaran secara bergilir, sedangkan 1 dosen yang lain bertugas mengontrol dan memonitor kegiatan belajar siswa bersama dengan 2 orang mahasiswa yang bertugas untuk membantu peserta kegiatan pembelajaran

Peserta mengikuti pelatihan pembelajaran Microsoft Office 2019 dengan 3 materi pelatihan yaitu pemahaman tentang Microsoft Office 2019, dan pembuatan mail merge di Word. Materi utama menjeskan tentang Microsoft Office 2019 yang merupakan Microsoft Office terbaru dan dilanjutkan dengan penjelasan tentang pembuatan mail merge di MS.Word. Pelaksanaan program ini bertujuan untuk meningkatkan keterampilan dan kemampuan siswa dalam membuat mail merge baik pembuatan surat, sertifikat maupun label dengan menggunakan Ms. Word.

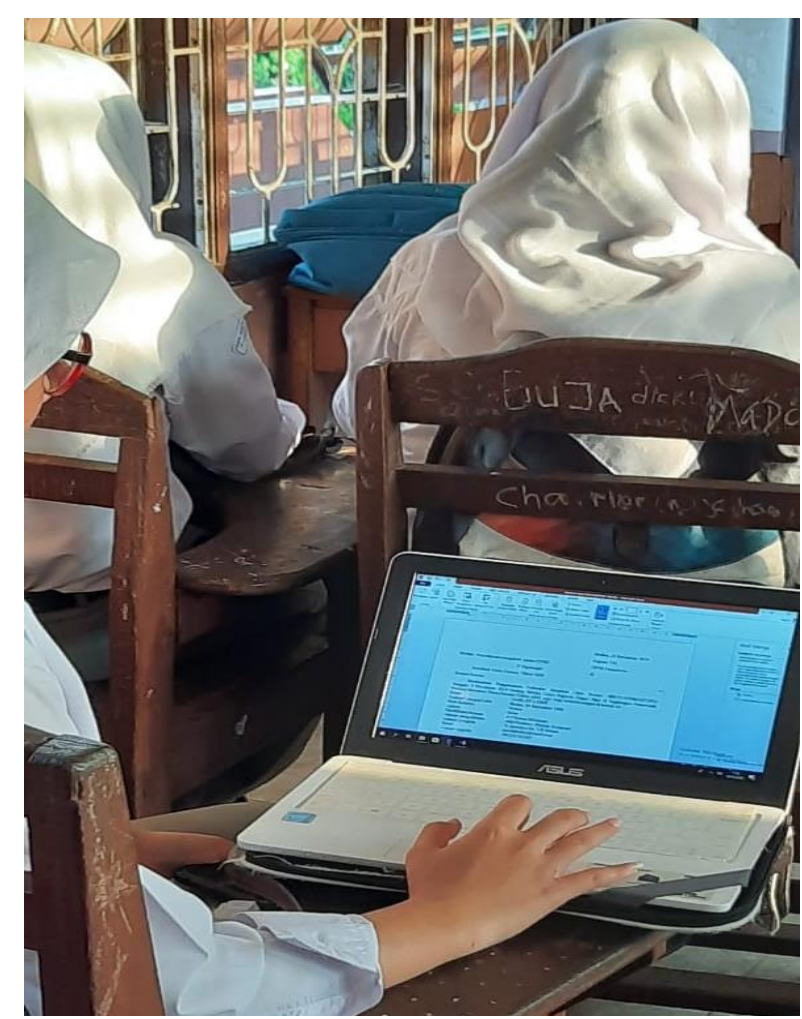

Gambar 2 Praktik Pembuatan Mail Merge

Setelah metode tutorial, tim memberikan tugas kepada peserta pelatihan untuk membuat mail merge untuk surat, sertifiat dan label. Ketika mereka membuat mail merge tim pengabdian dari mahasiswa membantu peserta yang kesulitan mengerjaan tugas pembuatan mail merge. 


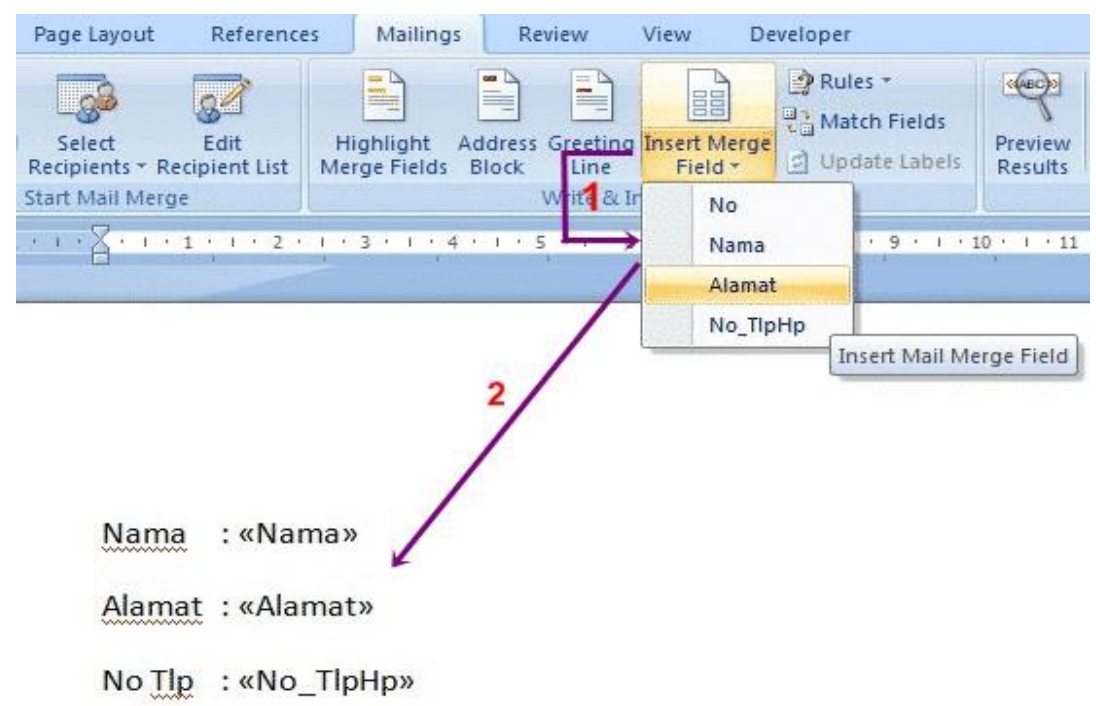

Gambar 3 Proses Pembuatan Mail Merge Untuk Surat

Hasil kegiatan PPM ini dapat dilihat dari hasil pembuatan tugas mail merge peserta pelatihan dari layar komputer masing-masing peserta yang berupa untuk surat, sertifikat dan label, terlihat sebagian besar peserta pelatihan dapat mengerjakan tugas tersebut dengan hasil yang sangat baik. Hal ini menandakan bahwa peserta pelatihan telah memahami bagaimana pembuatana mail merge dengan menggunakan Ms. Word tersebut. Hampir seluruh peserta kegiatan sepakat setelah mendapatkan pelatihan, kemampuan dan keterampilan dalam dalam pembuatan mail marge untuk pembuatan surat, sertifikat dan label dengan menggunakan $M S$ Word meningkat. Seluruh peserta juga memiliki harapan yang sama, yaitu menginginkan pelatihan yang berlanjut dan penambahan waktu kegiatan.

Evaluasi dilakukan melalui melihat hasil pekerjaan peserta dalam menyelesaikan tugas yang diberikan. Sebagian besar peserta dapat menyelesaikan membuat mail merge berupa surat, sertifikat dan lebel, dan sebagian kecil peserta yang belum dapat menyelesaikan tugas yang diberikan karena beberapa kendala yaitu waktu.

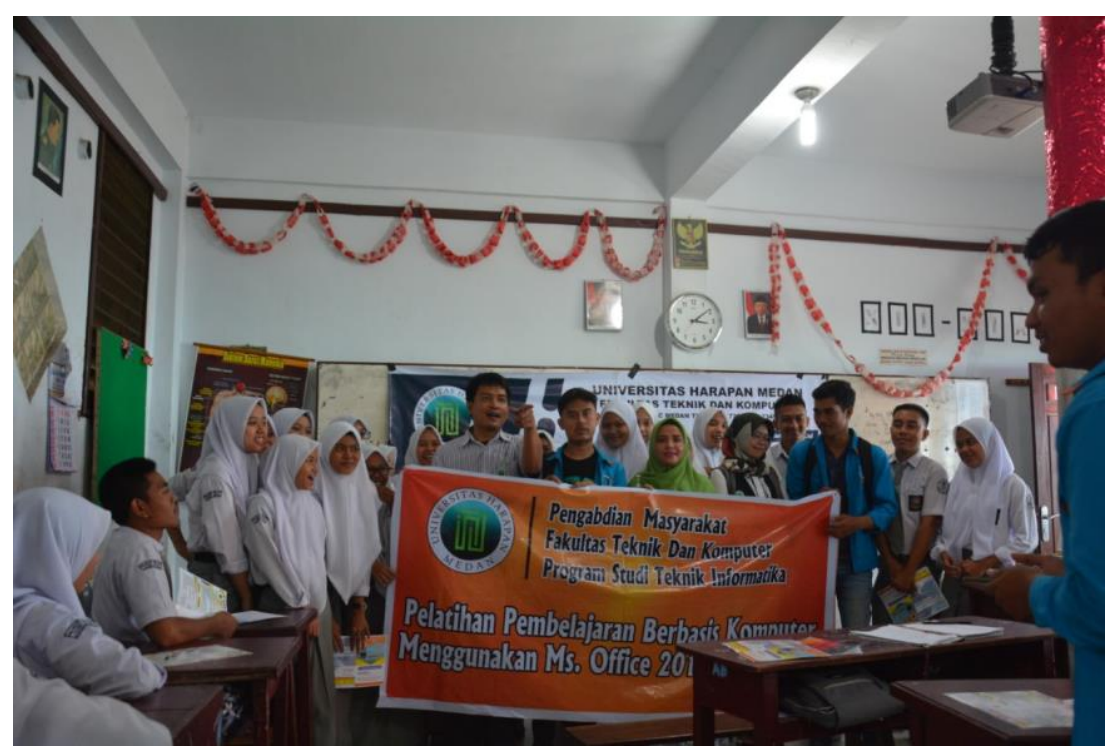

Gambar 4 Tim Pengabdian Pada Masyarakat

\subsection{Pembahasan}

Pelaksanaan semua kegiatan PPM di SMK Dwitunggal 1 Tanjung Morawa Kecamatan Deli Serdang berjalan baik dan lancar. Kegiatan ini memperoleh respond yang sangat baik dan positif 
dari seluruh peserta kegiatan dan juga guru-guru di sekolah tersebut. Hal ini disebabkan karena semua kegiatan yang dilaksanakan memberi kontribusi positif kepada seluruh peserta dan juga guru. Pelaksanaan kegiatan pelatihan Pembelajaran Berbasis Komputer Menggunakan Ms. Office 2019 Pada Siswa di SMK Dwitunggal 1 Tanjung Morawa, secara keseluruhan berjalan baik dan sukses. Suksesnya pelaksanaan kegiatan ini terlihat dari meningkatnya motivasi dan minat belajar peserta kegiatan, juga adanya peningkatan keterampilan mereka dalam membuat mail merge untuk surat, sertifikat dan label. egiatan ini diikuti oleh 38 orang siswa dari 40 orang siswa.

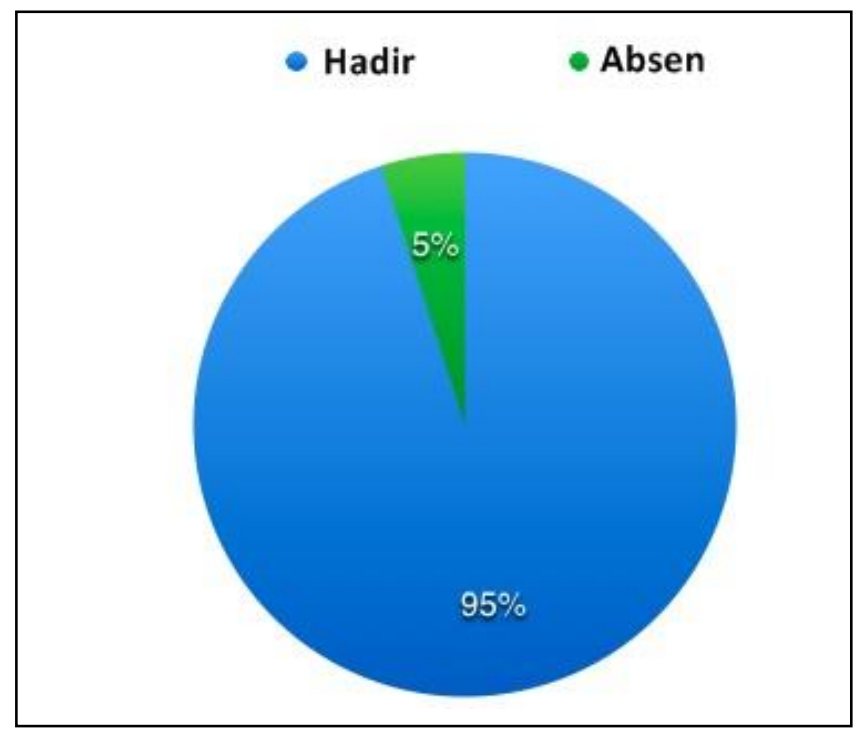

Gambar 5 Persentasi Kehadiran Peserta

Dari gambar diatas disimpulkan bahwa dari persentasi kehadiran 95\% siswa mengikuti kegiatan pengabdian dan sisanya 5\% siswa tidak mengikuti kegiatan ini karena sakit.Selama kegiatan pelatihan berlangsung, peserta kegiatan selalu menunjukkan antusiasme untuk terlibat langsung di dalamnya terutama ketika kegiatan praktik pembuatan mail merge. Mereka mampu menjawab pertanyaan-pertanyaan yang diberikan oleh tim pengabdian, juga menunjukkan rasa ingin tahu yang besar. Selain itu, peningkatan keterampilan pembuatan mail merge terlihat dari kemampuan menyelesaikan tugas yang diberikan oleh tim PPM.

Berdasarkan hasil kegiatan, dapat disimpulkan bahwa ada dua faktor penting penentu suksesnya kegiatan pengabdian ini yaitu metode dan media pembelajaran yang tepat dan sesuai dengan topik pembelajaran yang akan diajarkan. Metode dan media memiliki peran pembelajaran yang baik sangat efektif dalam pembelajaran (Yati, 2017). Karena penggunaan metode dan media yang tepat dapat memberi stimulus bagi siswa khususnya siswa SMK untuk belajar aktif dan kreatif dan tentunya memiliki motivasi untuk meningkatkan pengetahuan merea sesuai dengan bidang yang mereka pelajari.

\section{KESIMPULAN}

Pelaksanaan kegiatan PPM di SMK Dwitunggal 1 Tanjung Morawa Kecamatan Deli Sardang berjalan baik dan mencapai hasil yang diharapkan. Suksesnya kegiatan tersebut dapat dilihat dari proses pelaksanaannya dan hasil yang dicapai setelah kegiatan selesai dilaksanakan. Kegiatan Pelatihan Pelatihan Pembelajaran Berbasis Komputer Menggunakan Ms. Office 2019 Pada Siswa di SMK Dwitunggal 1 Tanjung Morawa memberi dampak positif bagi siswa peserta pelatihan, juga memberi kontribusi bagi pihak sekolah. Dampak positif ini ditunjukkan dengan adanya peningkatan kemampuan dan keterampilan pembuatan mail merge untuk surat, sertifikat dan label direalisasikan dengan kemampuan mreka dalam 
menjawab setiap pertanyaan dan terlibat aktif dalam setipa kegiatan pembelajaran serta tugas yang dapat diselesaikan dengan baik.

\section{UCAPAN TERIMA KASIH}

Tim kegiatan pengabdian pada masyarakat mengucapkan terima kasih kepada Ibu Kepala Sekolah Dwitunggal 1 Hermin Nurmianna, S.Pd yang telah memberikan izin untuk dapat melaksanakan kegiatan ini dengan baik. Dan ucapan terima kasih sebesar-besarnya kepada LPPM Universitas Harapan Medan yang telah mendanai kegiatan ini.

\section{DAFTAR PUSTAKA}

Abdul Kadir \& Terra Ch. Triwahyuni. 2013. Pengenalan Teknologi Informasi. Yogyakarta.

Muldiani, R.F. (2011). Media Pembelajaran Berbasis Animasi Komputer Pada Mata Kuliah Fisika Terapan UntukProgram Studi Teknik Aeronautika Politeknik Negeri Bandung. Sigma-Mu, 3(1):11-20.

Dudung M.N, Suparti, Sulastri. (2017). Pelatihan Penyusunan Perangkat Pembelajaran Berbasis Tik Bagi Guru Akuntansi Smk. DINAMISIA-Jurnal Pengabdian Kepada Masyarakat, 2 (2), 256-260

Depdiknas. (2003). Undang-undang RI No. 20 tahun 2003, Tentang Sistem Pendidikan Nasional.

Thunder, J. (2018). Pentingnya 'Hardskill' dan 'Softskill' dalam Dunia Karir. Retrieved February 28, 2020, from https://www.kompasiana.com/

Hutahaean, J., Azhar, Z., Siagian, Y., Syah, A. Z., \& Informasi, S. (2019). Pelatihan Pembuatan Blog Pada Siswa Lembaga Kursus Pendidikan (lkp) Mandiri. Jurdimas, 2(1), 65-74.

Roki H, Lucky L.V, Fana W. (2019). Pelatihan Office Perkantoran Di Sma Pgri Pekanbaru Sebagai Bekal Menyonsong Revolusi Industri 4.0, DINAMISIA-Jurnal Pengabdian Kepada Masyarakat, 3 (1), Hal. 53-61.

Putra, Buana Suhurdin. (2011). Membuat Surat Massal dalam Sekejap dengan Mail Merge MS Word 2007. Jakarta: Media Kita

Johnie, R, Swanda Pasaribu. (2019). Belajar Microsoft Office (Word, Excel, Powerpoint) 2019, Deepublish, Yogyakarta.

Sutabri, T. (2014). Pengantar Teknologi Informasi. Penerbit Andi, Jakarta- Indonesia. 